\title{
PEMBAHARUAN SANKSI PIDANA BERDASARKAN FALSAFAH PANCASILA DALAM SISTEM HUKUM PIDANA DIINDONESIA
}

\author{
Tommy Leonard \\ Fakultas Hukum Universitas Prima Indonesia, Medan \\ Email:tommy@unprimdn.ac.id
}

\begin{abstract}
Since Indonesia's Law Number 1 of 1946 concerning Criminal Law (hereinafter referred to as the Criminal Code) applied, criminal law reformed to continue till now, both the modernity of the criminal law material, formally criminal law, and criminal law enforcement. The third part of the criminal law is part of the criminal law integratted to criminal law reform which must be involved to all three parts so they can be implemented. To achieve the objective of sentencing, Bill Criminal Code of 2012 also formulated a modernity of criminal code. types consist of three types. First, the principal of the criminal consisting of imprisonment, criminal cover, criminal surveillance, criminal fines, and criminal social work. Second, the criminal subject of a special nature, namely the death penalty. Third, the additional penalty which consists of the removal of certain rights, deprivation of certain goods and / or bill, the judge's verdict, payment of compensation, and the fulfillment of obligations of local customs or obligations under the laws of living in society. A appropriate theory and the theory improvement prevention of criminal penalties is an approach based on instrumental perspective. The punishment had been seen as an instrument to achieve certain objectives that lies beyond the punishment itself, namely the improvement of the perpetrator or the people protection. The nature and modalities of punishment must be tailored to the objectives which would be achieved. Thus, the imposition of punishment has no meaning in itself, but deriving their value from something else, namely from those objectives. The implication is that if the penalty is only seen as a means, basically can be replaced by other means which may be more efficient.
\end{abstract}

Keywords: criminal code, concept, Pancasila

\begin{abstract}
Abstrak
Sejak Undang-Undang nomor 1 tahun 1946 tentang Peraturan Hukum Pidana (selanjutnya disebut KUHP) berlaku, pembaharuan hukum pidana terus berlangsung hingga saat ini, baik pembaharuan terhadap hukum pidana material, hukum pidana formal, maupun hukum pelaksanaan pidana. Ketiga bagian hukum pidana tersebut merupakan bagian dari hukum pidana yang terintegral sehingga pembaharuan hukum pidana harus melibatkan ketiga bagian tersebut agar dapat dilaksanakan. Untuk mencapai tujuan pemidanaan, RUU KUHP Tahun 2012 juga merumuskan pembaharuan jenis pidana. Pembaharuan tersebut terdiri atas tiga jenis. Pertama, pidana pokok yang terdiri atas pidana penjara, pidana tutupan, pidana pengawasan, pidana denda, dan pidana kerja sosial. Kedua, pidana pokok yang bersifat khusus, yaitu pidana mati. Ketiga, pidana tambahan yang terdiri atas pencabutan hak tertentu, perampasan barang tertentu dan/atau tagihan, pengumuman putusan hakim, pembayaran ganti


kerugian, dan pemenuhan kewajiban adat setempat atau kewajiban menurut hukum yang hidup dalam masyarakat. Pendekatan teori perbaikan dan teori prevensi tentang hukuman pidana adalah pendekatan berdasarkan perspektif instrumentalistik. Hukuman dipandang sebagai instrumen untuk mencapai tujuan tertentu yang terletak di luar hukuman itu sendiri, yakni perbaikan pelaku atau perlindungan masyarakat. Sifat dan modalitas dari hukuman harus disesuaikan pada tujuan yang mau dicapai. Jadi, Penjatuhan hukuman tidak memiliki makna dalam dirinya sendiri, tetapi memperoleh nilainya dari sesuatu yang lain, yakni dari tujuan itu. Implikasinya adalah jika hukuman hanya dipandang sebagai sarana, pada dasarnya dapat diganti dengan sarana-sarana lain yang mungkin lebih efisien. Teori hukuman instrumentalistik mengimplikasikan penghapusan hukuman.

Keyword: Hukum Pidana, Konsep, Pancasila

\section{A. PENDAHULUAN}

Upaya pembaharuan Kitab Undang-Undang Hukum Pidana (KUHP) tersebut dilatarbelakangi sejarah kolonialisme Belanda di Indonesia. Dahulu, Belanda memberlakukan KUHP negaranya pada negara jajahannya, termasuk di Indonesia (dahulu dikenal sebagai Hindia Belanda). Sebagai warisan dari kolonialisme yang keberlakuannya dipaksakan di Indonesia, KUHP saat ini dirasakan tidak sesuai dengan jiwa bangsa Indonesia dan perlu dilakukan pembaharuan.

Untuk memiliki hukum pidana yang sesuai dengan karakteristik bangsa Indonesia, Muladi berpendapat bahwa pembaharuan hukum pidana material perlu memperhatikan karakteristik operasional hukum pidana material di masa mendatang. Misalnya, hukum pidana material harus disusun dalam kerangka ideologi nasional; memperhatikan aspekaspek yang berkaitan dengan kondisi manusia, alam, dan tradisi Indonesia; dapat menyesuaikan diri dengan kecenderungan- kecenderungan universal yang tumbuh dalam pergaulan masyarakat beradab; memikirkan aspek-aspek yang bersifat preventif; dan harus tanggap terhadap perkembangan ilmu pengetahuan dan teknologi guna peningkatan efektivitas fungsinya dalam masyarakat.

Berbagai pembaharuan jumlah maksimal denda pada KUHP telah dilakukan beberapa kali, hal itu tidak membuat pidana denda lepas dari kritikan. Batas jumlah maksimal penentuan pidana denda yang dilakukan secara parsial dan tidak adanya polapola tertentu menunjukkan bahwa tujuan pembaharuan pidana denda tidak jelas dan tidak memiliki landasan falsafah dan pedoman yang jelas.

Selain pidana pokok, KUHP juga mengenal pidana tambahan, yaitu pidana yang bersifat menambah pidana pokok yang dijatuhkan. Pidana ini tidak dapat berdiri sendiri, 
kecuali dalam hal-hal tertentu seperti perampasan barang-barang tertentu. Pidana tambahan ini bersifat fakultatif, artinya dapat dijatuhkan, tetapi tidak harus.

Perkembangan sanksi pidana di Indonesia menimbulkan pertanyaan mengenai hakikat pemidanaan. Sebagai bangsa yang memiliki falsafah Pancasila, sanksi pidana harus dilaksanakan dengan menggunakan perspektif Pancasila untuk merumuskan apa yang baik dan benar bagi masyarakat Indonesia.

Berbagai pembaharuan sanksi pidana di Indonesia tidak pernah lepas dari kontroversi yang dipengaruhi oleh perkembangan kemanusiaan, khususnya terhadap pembaharuan sanksi pidana yang diajukan dalam RUU KUHP Tahun 2012. Sebagai bangsa yang memiliki Pancasila sebagai falsafah hidup, sanksi pidana merupakan bagian dari sistem hukum pidana yang tidak terlepas dari sistem hukum nasional yang berorientasi pada Pancasila yang mengandung keseimbangan antara moral religius (ketuhanan), kemanusiaan (humanistik), kebangsaan, demokrasi, dan keadilan sosial (Barda Nawawi Arief, 2004: 5). Oleh karena itu, dalam melakukan pembaharuan sanksi pidana perlu dilakukan pengkajian dan penggalian nilai-nilai nasional yang bersumber pada Pancasila.

Berdasarkan atas uraian latar belakang permasalahan di atas, penulis merumuskan masalah bagaimanakah kedudukan Pancasila dalam pembaharuan sanksi pidana dalam sistem hukum pidana di Indonesia?

\section{B. PEMBAHASAN}

\section{Kedudukan Pancasila dalam Pembaharuan Sanksi}

Kebaikan hanya dapat terwujud jika ada cinta manusia terhadap sesamanya, dan cinta ini hanya akan terwujud jika ada keadilan. Kondisi keadilan akan terbentuk jika ada hukum yang akan menjadi sarana bagi penyelenggaraan cinta kepada sesama tersebut. Dengan demikian, sudah seharusnyalah hukum itu bersumber pada akal budi. Jika hukum disusun supaya dapat mengikat perbuatan manusia, hukum harus adil dan membimbing manusia menuju tujuan akhir, yaitu kebaikan.

Dalam hubungan antara interaksi sosial dan keberlakuan hukum kecenderungan untuk mempertahankan diri, kecenderungan untuk hidup bermasyarakat, kecenderungan untuk memperoleh kebenaran, dan kecenderungan untuk berbuat atas putusan akal. Keempat wujud keberlakuan hukum tersebut sangat relevan dengan sifat-sifat hakiki Pancasila yang secara kodrat menempatkan manusia sebagai makhluk Tuhan yang satu yang bercita-cita untuk keberadaan manusia, sebagai 
makhluk yang bersatu dengan lingkungannya berdasarkan rasa persaudaraan, dan sebagai makhluk yang harus hidup bersama dan berkehendak untuk menciptakan keadilan yang bersifat sosial bagi masyarakat Indonesia.

Indonesia sebagai suatu sistem yang berisi kumpulan orang- orang yang berbeda, tetapi satu karena persatuanny dengan meniadakan perbedaan suku, agama, ras, dan antargolongan melebur dalam berbagai aspek. Pancasila adalah ideologi (keyakinan) bangsa Indonesia yang menghendaki agar manusia Indonesia sebagai manusia yang berketuhanan, berkemanusiaan, mempersatukan manusia akan cita-cita kemanusiaannya, bercakap-dengar dengan manusia lainnya, dan adil sebagai dasar cita akan keadilan. Pancasilalah yang dapat menjadi tolok ukur untuk dapat disebut sebagai "manusia Indonesia yang seutuhnya".

Hakikat hukum menurut Pancasila untuk keluarga besar bangsa Indonesia adalah hukum yang berketuhanan, berkemanusiaan, mengutamakan persatuan dan kejayaan Indonesia, berkerakyatan, dan tentunya berkeadilan. Selain itu, Pancasila adalah etika yang menjadi tolok ukur untuk dapat disebut sebagai "manusia Indonesia yang seutuhnya". Manusia Indonesia yang seutuhnya adalah manusia yang memenuhi hukum keindonesiannya. Hukum keindonesiaan ini pula yang menuntun bangsa Indonesia dalam bersikap dan bertindak, baik kepada sesama maupun lingkungannya.

Sejalan dengan perkembangan peradaban manusia, hukum tidak bersifat statis, tetapi bersifat dinamis yang dipengaruhi terus-menerus sesuai dengan kebutuhan dan kemauan masyarakat. Sistem hukum yang sesuai di Indonesia adalah sistem hukum yang dilandasi oleh nilai- nilai kehidupan dan kebudayaan bangsa Indonesia, yaitu Pancasila yang oleh para founding father telah ditetapkan sebagai dasar falsafah bangsa dan negara. Dengan demikian, tatanan sistem hukum nasional harus mengacu pada cita hukum (rechtsidee) Pancasila.

Beberapa ahli hukum memberikan pendapatnya mengenai ciri-ciri sisem hukum nasional yang berdasarkan Pancasila. Menurut Prasetyo, sistem hukum nasional yang sesuai dengan nilai-nilai yang hidup di masyarakat Indonesia adalah sistem hukum nasional berdasarkan Pancasila yang mencakup nilai-nilai berikut.

a. Ketuhanan yang Maha Esa

Pembentukan hukum di Indonesia harus dilandasi oleh nilai-nilai ketuhanan atau keagamaan. Selain itu, hukum harus memberikan jaminan kebebasan 
beragama dan tidak boleh mengistimewakan salah satu agama dan menganaktirikan agama lainnya.

b. Kemanusiaan yang adil dan beradab

Setiap pembentukan hukum harus ada jaminan dan penghormatan terhadap hakhak asasi manusia.

c. Persatuan Indonesia

Hukum harus memperhatikan persatuan dan integritas bangsa dan negara. Pembentukan hukum tidak boleh memicu perpecahan (disintegrasi) bangsa dan negara.

d. Kerakyatan yang dipimpin oleh hikmat kebijaksanaan dalam permusyawaratan perwakilan

Pembentukan hukum harus dilandasi dengan nilai-nilai demokrasi yang melibatkan semua unsur yang ada di negara, baik pemerintah, legislatif, maupun masyarakat.

e. Keadilan sosial bagi seluruh rakyat Indonesia

Pembentukan hukum nasional harus bertujuan untuk memberikan keadilan dan kesejahteraan bagi seluruh rakyat Indonesia.

Sistem hukum yang berdasarkan Pancasila dapat memberikan keseimbangan di antara nilai-nilai yang bertentangan dalam masyarakat. Sistem hukum harus mampu memberikan titik- titik keseimbangan dalam upaya negara melakukan pembangunan yang perubahannya sangat cepat yang akan menghilangkan keseimbangan lama, baik dalam hubungan antarindividu mauun kelompok dalam masyarakat. Selain itu, sistem hukum nasional akan membuat harmonisasi hukum dan menghilangkan pluralisme sistem hukum sehingga sistem hukum nasional yang harmonis dalam arti selaras, serasi, seimbang, dan konsisten, serta menghindari pertentangan norma hukum satu dengan norma hukum lainnya dapat terbentuk.

\section{Konsep Sanksi Pidana dalam RUU KUHP Tahun 2012 dan Perbandingannya dengan KUHP Negara Lain}

1) Konsep Pidana Penjara

Upaya pembaharuan terhadap pelaksanaan pidana penjara mulai diperbaiki pascakemerdekaan Indonesia. Sistem kepenjaraan yang selama ini digunakan sebagai sistem perlakuan terhadap orang- orang hukuman menjadi sistem lain yang lebih 
sesuai dengan bangsa Indonesia dibandingkan dengan sistem sebelumnya sebagai warisan kolonial Belanda. Sistem yang dianggap akan berhasil menggantikan sistem tersebut adalah sistem yang sesuai dengan kepribadian bangsa Indonesia, yaitu sistem yang berdasarkan Pancasila.

Sistem kepenjaraan yang memperlakukan narapidana sebagai orang-orang hukuman tidak sebagai anggota masyarakat. Sistem kepenjaraan lebih mengutamakan pencabutan kemerdekaan dan pemeliharaan serta ketertiban lembaga daripada membina narapidana menjadi masyarakat yang baik. Sistem kepenjaraan menggunakan filosofis pembalasan dan pen"jera"an dengan wujud penderitaan dan penyiksaaan.

Rehabilitasi sebagai tujuan pemidanaan mulai berkembang pada abad ke-19 untuk memperbaiki pelaku. Dasar pertimbangan yang digunakan adalah sistem kepenjaraan dan penerapannya merupakan produk kolonial yang tidak sesuai lagi dengan kondisi Indonesia yang sudah merdeka sehingga harus disesuaikan dengan sistem sosial negara Indoensia. Pembaharuan tersebut dimulai dengan diperkenalkannya istilah "permasyarakatan” oleh Dr. Saharjo pada tahun 1963. Beliau menyampaikan bahwa permasyarakatan merupakan tujuan pidana penjara sehingga lembaga pemasyarakatan banyak mengandung nilai- nilai resosialisasi.

2) Konsep Pidana Tutupan

Pidana tutupan merupakan jenis sanksi yang sebelumnya tidak diatur dalam KUHP. Pidana tutupan mulai diperkenalkan di Indonesia melalui Undang-Undang nomor 20 tahun 1946 tentang Hukuman Tutupan. pidana tutupan merupakan alternatif pidana penjara karena pelaku terdorong melakukan tindak pidana karena alasan yang patut dihormati. Pelaksanaan pidana tutupan berbeda dengan pidana penjara karena ditempatkan di tempat khusus bernama Rumah Tutupan yang pengurusan umumnya dipegang oleh Menteri Pertahanan (Peraturan Pemerintah No. 8 Tahun 1948 tentang Rumah Tutupan). Walaupun berbeda pelaksanaannya, penghuni Rumah Tutupan juga wajib melaksanakan pekerjaan yang diperintahkan kepadanya dengan jenis pekerjaan yang diatur oleh Menteri Pertahanan dengan persetujuan Menteri Kehakiman. Penghuni Rumah Tutupan tidak boleh dipekerjakan saat hari Minggu dan hari raya, kecuali jika mereka sendiri yang menginginkan

\section{2) Konsep Pidana Pengawasan}

Pidana pengawasan merupakan jenis sanksi pidana yang sebelumnya dikenal dengan pidana penjara bersyarat pada Pasal 14A ayat (1) KUHP. Terpidana tidak 
menjalani pidana penjara, kecuali jika selama masa percobaan terpidana telah melanggar syarat-syarat umum atau khusus yang telah ditentukan oleh pengadilan (pidana bersyarat merupakan penundaan pelaksanaan pidana). Menurut RUU KUHP tahun 2012, pidana pengawasan termasuk dalam pidana pokok yang bersifat alternatif dari pidana penjara maksimal 7 tahun penjara. Pidana tersebut untuk menghindari dampak buruk penjara terhadap pelaku dengan pertimbangan keadaan dan perbuatan pelaku. Pidana pengawasan memiliki keuntungan bagi terpidana dan masyarakat.

Pidana pengawasan tidak boleh digunakan sebagai bentuk dari kemurahan hati, pemberian ampun, atau pembebasan pelaku dari tindak pidana. Oleh karena itu, perlu adanya pembatasan tindak pidana yang dapat dikenakan pidana pengawasan yang dibatasi oleh undang-undang. Tindak pidana yang berkaitan dengan kekerasan, kejahatan terhadap moral, kejahatan yang melibatkan penggunaan senjata mematikan, kejahatan karena dibayar oleh orang lain, kejahatan terhadap pemerintah, dan kejahatan yang diancam pidana tertentu merupakan tindak pidana yang tidak boleh dijatuhi pidana pengawasan. Hal ini sebagai bentuk perlindungan kepada masyarakat karena pelaku tindak pidana tersebut memerlukan waktu untuk dibina dalam lembaga institusional (lembaga pemasyarakatan). Dengan demikian, pidana pengawasan tidak hanya bertujuan untuk melindungi kepentingan terpidana, tetapi juga kepentingan masyarakat agar tujuan pemidanaan dapat terlaksana.

\section{3) Konsep Pidana Denda}

Sistem pidana denda di beberapa negara mengenal pidana denda harian, seperti Finlandia dan Denmark. Di Finlandia pidana denda umumnya dihitung dengan menggunakan gaji atau upah harian yang diperoleh terpidana. Jumlah harian pidana penjara dapat diganti dengan denda berdasarkan perolehan upah khusus tindak pidana ringan seperti pelanggaran lalu lintas, pembuangan sampah sembarangan, dan gangguan keamanan.

Konsep pidana denda di Denmark hampir sama dengan di Finlandia dengan menggunakan bentuk denda harian dengan minimal 1 hari dan maksimal 60 hari denda. Untuk tindak pidana yang dilakukan bersamaan jumlah denda tidak dibatasi (sesuai jumlah masing-masing delik). Jumlah denda tidak hanya memperhatikan pengahsilan terpidana, tetapi juga mempehatikan hal-hal lain, seperti sumber modal, kekayaaan terpidana, dan kewajiban terpidana terhadap keluarga. Dalam batas- batas tertentu, polisi dan penuntut umum dapat mengenakan denda untuk menghindari 
penuntutan pidana. Pidana denda yang tidak bisa dibayar akan diganti dengan pidana penjara yang ditetapkan hakim.

\section{4) Konsep Pidana Kerja Sosial}

Pidana kerja sosial merupakan salah satu pembaharuan dalam sanksi pidana pokok. Sanksi ini tidak diatur dalam RUU KUHP 2012. Pidana kerja sosial merupakan upaya untuk mencari alternatif pidana perampasan kemerdekaan bertolak dari kenyataan bahwa pidana perampasan kemerdekaan semakin tidak disukai, baik dengan pertimbangan kemanusiaan, pertimbangan filosofis, maupun pertimbangan ekonomis.

Atas pertimbangan kemanusiaan, pidana perampasan kemerdekaan semakin tidak disukai karena mempunyai dampak negatif yang tidak kecil. Dampak tersebut tidak saja terhadap narapidana, tetapi juga terhadap keluarga serta orang-orang yang kehidupannya tergantung dari narapidana tersebut. Beberapa dampak negatif pidana perampasan kemerdekaanterhadap narapidana antara lain sebagai berikut:

\section{a. Loos of personality}

Seorang narapidana dapat kehilangan kepribadian atau identitas diri akibat peraturan dan tata cara hidup di lembaga pemasyarakatan.

\section{b. Loos of security}

Selama menjalani pidana, narapidana selalu dalam pengawasan petugas sehingga merasa kurang aman dan merasa selalu dicurigai atas tindakannya.

\section{c. Loos of liberty}

Dengan dikenai pidana jelas kemerdekaan individualnya terampas. Hal ini dapat menyebabkan perasaan tertekan, pemurung, dan mudah marah sehingga dapat menghambat proses pembinaan.

d. Loos of personal communication

Dengan menjalani pidana di lembaga pemasyarakatan kebebasan untuk berkomunikasi dengan siapapun dibatasi.

e. Loos of good and service

Selama di lembaga pemasyarakatan, narapidana dapat merasa kehilangan pelayanan yang baik karena semua harus dikerjakan sendiri.

f. Loos of heterrosexual 
Dengan pembatasan bergerak dan penempatan narapidana menurut jenis kelamin jelas narapidana akan merasakan terampasnya naluri seks, kasih sayang, dan kerinduan pada keluarga.

\section{g. Loos of practige}

Selama dalam lembaga pemasyarakatan dan munculnya perlakuan yang bermacam-macam, baik dari petugas maupun sesama narapidana lainnya, dapat menghilangkan harga dirinya.

\section{h. Loos of belief}

Akibat perampasan kemerdekaan di lembaga pemasyarakatan narapidana dapat menjadi kehilangan rasa percaya diri.

\section{i. Loos of creativity}

Narapidana selama menjalani pidananya di lembaga pemasyarakatan karena perasaan tertekan dapat kehilangan daya kreativitas, gagasan- gagasan, dan imajinasinya.

\section{5) Konsep Pidana Tambahan dalam KUHP}

Selain pidana pokok, KUHP juga mengatur mengenai pidana tambahan, yaitu pidana yang bersifat suplemen agar tujuan pemidanaan dapat tercapai. Pidana tambahan disebut dalam Pasal 10 KUHP pada bagian bab II yang terdiri atas (a) pencabutan hak-hak tertentu, (b) perampasan barang-barang tertentu, dan (c) pengumuman keputusan hakim. Melihat namanya, sudah nyata bahwa pidana tambahan ini hanya bersifat menambah pidana pokok yang dijatuhkan.

Mengenai pelaksanaan putusan yang berupa pidana denda, Kitab UndangUndang Hukum Acara Pidana (KUHAP) hanya mengatur dalam 1 pasal saja, yaitu Pasal 273 ayat (1) yang berbunyi jika putusan pengadilan menjatuhkan pidana denda, kepada terpidana diberikan jangka waktu 1 bulan untuk membayar denda tersebut, kecuali dalam putusan acara pemeriksaan cepat yang harus seketika dilunasi. Dalam ayat tersebut, jangka waktu tersebut dapat diperpanjang paling lama 1 bulan. Namun, perlu diingat jika dijatuhkan pidana denda dengan subsidair pidana kurungan pengganti, terpidana dapat melunasi separuh dendanya dan separuhnya lagi dijalani sebagai pidana kurungan. 
Peraturan lama (Herzien Inlandsch Reglement / HIR) pada Pasal 379 menyatakan bahwa upah dan ganti kerugian bagi pokrol, penasihat, atau pembela dan wakil tidak boleh dimasukkan dalam pidana membayar ongkos perkara, tetapi harus ditanggung selalu oleh pihak yang meminta bantuan pada orang yang demikian itu atau berwakil kepadanya. Karena pemanggilan saksi-saksi, ahli juru bahasa, dan sebagainya untuk menghadap di persidangan dilakukan oleh jaksa, jelas bahwa perhitungan ongkos perkara pidana itu ada pada jaksa dan hakim. Perhitungan itu seharusnya diajukan dalam tuntutannya (requisitoir).

Praktik yang biasa dilakukan jaksa dewasa ini adalah jika terpidana tidak membayar biaya perkara, agar tidak merupakan tunggakan hasil dinas kejaksaan, jaksa meminta keterangan tidak mampu dari pamong praja bagi terpidana untuk membebaskannya dari pembayaran dan menghapuskan sebagai tunggakan, tetapi tidak tepat karena hal semacam itu hanya berlaku untuk biaya perkara perdata (Pasal 237 dan seterusnya Herzien Inlandsch Reglement / HIR).

\section{Konsep dan Bentuk Sanksi Pidana yang Sesuai dengan Filsafat Pancasila dan Prospeknya dalam Pembaharuan Sistem Pemidanaan di Indonesia}

1) Filsafat Pemidanaan

Manfaat yang diberikan dari penjatuhan hukuman pidana tersebut didukung oleh John Andenaes yang menyatakan bahwa pidana harus dapat memiliki manfaat berupa pencegahan kepada pelaku untuk melakukan kejahatan (special preventif), pencegahan kepada masyarakat umum untuk tidak melakukan kejahatan (general preventif), dan memberikan pengaruh untuk memperkuat moral masyarakat dan mendorong perilaku patuh pada hukum (Saleh, Roeslan, 1987:36). Pendapat lainnya menyatakan bahwa pidana bertujuan untuk menakuti (deterrence) pelaku kejahatan. Tujuan tersebut diberikan agar pelaku jera melakukan kejahatan, kepada masyarakat agar masyarakat lain takut untuk melakukan kejahatan, dan tujuan yang bersifat jangka panjang agar keserasian hidup masyarakat dapat terjaga.

Konsep pemidanaan disampaikan melalui konsep restoractive justice yang menempatkan nilai yang lebih tinggi dalam keterlibatan langsung dari pihak. Korban mampu untuk mengembalikan unsur kontrol, sedangkan pelaku didorong untuk memikul tanggung jawab sebagai sebuah langkah dalam memperbaiki kesalahan yang disebabkan tindak kejahatan dan dalam membangun sistem nilai sosialnya. Keterlibatan komunitas aktif memperkuat komunitas itu sendiri dan mengikat komunitas akan nilai-nilai untuk menghormati dan rasa saling mengasihi antara 
sesama. Peranan pemerintah secara substansial berkurang dalam memonopoli proses peradilan sekarang ini.

Restorative justice membutuhkan usaha-usaha yang kooperatif dari komunitas dan pemerintah untuk menciptakan sebuah kondisi korban dan pelaku dapat merekonsiliasikan konflik dan memperbaiki luka- lukanya. Restorative justice mengembalikan konflik kepada pihak-pihak yang paling terkena pengaruh seperti korban, pelaku, dan kepentingan komunitasnya, serta memberikan keutamaan pada kepentingan- kepentingannya. Restorative justice juga menekankan pada hak asasi manusia dan kebutuhan untuk mengenali dampak dari ketidakadilan sosial dan dalam cara-cara yang sederhana untuk mengembalikan daripada secara sederhana memberikan pelaku keadilan formal atau hukum dan korban tidak mendapatkan keadilan apapun. Restorative justice juga mengupayakan untuk me-restore keamanan korban, penghormatan pribadi, martabat, dan yang lebih penting adalah sense of control.

Barbagai tujuan pemidanaan yang disampaikan di atas tidak tertulis dalam KUHP, tetapi secara tersirat menyampaikan beberapa tujuan pemidanaan. KUHP menyatakan bahwa hakim mempertimbangkan hal-hal yang memberatkan (memberikan keterangan yang berbelit-belit, tidak menyesali perbuatannya, dan mangkir) dan hal yang meringankan terdakwa (terdakwa masih muda, sopan dalam proses peradilan, mengakui dan menyesali perbuatannya, dan belum pernah dihukum sebelumnya).

Pascakemerdekaan Indonesia yang memiliki filsafat Pancasila sehingga tujuan pemidanaan harus disesuaikan dengan mengedepankan prinsip-prinsip pemidanaan dalam pandangan filsafat Pancasila yang dilakukan sesuai dengan budaya yang dianut bangsa Indonesia dengan memperhatikan prinsip-prinsip berikut.

1) Pengakuan manusia sebagai mahluk Tuhan yang Maha Esa sehingga wujud pemidanaannya tidak boleh bertentangan dengan keyakinan agama maupun kepercayaan yang dianut oleh masyarakat Indonesia. Pemidanaan terhadap seseorang harus diarahkan pada penyadaran iman dari terpidana sehingga dapat bertobat menjadi manusia yang beriman dan taat. Dalam hal ini, pemidanaan harus berfungsi sebagai pembinaan mental orang yang dipidana dan mentransformasikan terpidana menjadi orang yang religius (Sahetapy, J. E., 1982: 284). 
2) Pengakuan terhadap keluhuran harkat dan martabat manusia sebagai ciptaan Tuhan. Pemidanaan tidak boleh mencederai hak- hak asasinya yang paling dasar dan jaminan atas hak hidup. Hak ini adalah hak yang tidak dapat dikurangi dalam keadaan apapun (non derogable right) serta tidak boleh merendahkan martabatnya dengan alasan apapun. Implikasinya adalah walaupun terpidana berada dalam lembaga pemasyarakatan, unsur-unsur dan sifat perikemanusiaannya tidak boleh dikesampingkan demi membebaskan yang bersangkutan dari pikiran, sifat, kebiasaan, dan tingkah laku jahatnya.

3) Solidaritas kebangsaan dengan orang lain sebagai sesama warga bangsa. Pelaku harus diarahkan pada upaya meningkatkan toleransi dengan orang lain, memumbuhkan kepakaan terhadap kepentingan bangsa, dan mengarahkan untuk tidak melakukan kejahatan. Dengan kata lain, pemidanaan perlu diarahkan untuk menanamkan rasa kecintaan terhadap bangsa (Sahetapy, J. E., 1982: 284).

4) Menumbuhkan kedewasaan sebagai warga negara yang berkhidmat, mampu mengendalikan diri, disiplin, dan menghargai, serta menaati hukum sebagai wujud keputusan rakyat (Sahetapy, J. E., 1982: 284).

5) Menimbulkan kesadaran kewajiban setiap individu sebagai makhluk sosial yang menjunjung keadilan bersama orang lain sebagai sesama warga masyarakat. Perlu diingat bahwa pemerintah dan rakyat harus ikut bertanggung jawab untuk membebaskan terpidana dari kemelut dan kekejaman kenyataan sosial yang melilitnya menjadi pelaku tindak pidana (Sahetapy, J. E., 1982: 284).

\section{2) Konsep Pidana Kerja Sosial Menurut Filsafat Pancasila}

Pidana kerja sosial selaras dengan sila kelima Pancasila yang di dalamnya terkandung nilai bekerja keras dalam menjalani pemidanaan. Kerja keras adalah salah satu sarana utama untuk menuju keadilan sosial. Pidana kerja sosial juga sesuai dengan nilai-nilai sila kedua, . Dalam sila kedua tersebut terkandung nilai-nilai pengakuan terhadap martabat manusia karena manusia Indonesia adalah bagian dari warga masyarakat dunia yang berharkat dan bermartabat sama sebagai hamba Tuhan. Manusia dituntut berlaku adil dan menghormati hak asasi lainnya dan memandang nilai penghormatan terhadap hak dan kewajiban manusia.

Dalam pidana kerja sosial juga terkandung nilai pengayoman, yaitu mengayomi narapidana dari pergaulan kelompok kriminal lain yang dapat mengakibatkan narapidana bertambah jahat, mengayomi narapidana agar dapat hidup layak di kemudian hari, dan mengayomi narapidana dari balas dendam masyarakat atau korban 
kejahatan. Nilai-nilai Pancasila tersebut harus dilihat dari suatu kebulatan karena, meskipun nilai-nilai tersebut dapat dibedakan, pada hakikatnya tidak dapat dipisahkan.

Manfaat pidana kerja sosial bagi pelaku adalah dapat meberikan kesempatan untuk menyumbang kepada masyarakat dengan bekerja untuk masyarakat dan memberikan kesempatan untuk mengembangkan sikap positif, keahlian, dan kepercayaan diri. Manfaat pidana kerja sosial bagi lembaga atau institusi yang berperan serta menyediakan tempat untuk melakukan pidana kerja sosial adalah memberikan pelaku kesempatan untuk ikut dalam program-program masyarakat dan mempelajarinya dan tersedianya sukarelawan untuk membantu di tempat kerja. Sementara itu, manfaat pidana kerja sosial untuk masyarakat luas adalah pidana kerja sosial lebih ringan biayanya dengan mempekerjakan pelaku di dalam masyarakat daripada memasukkannya ke penjara.

3) Pidana Denda Menurut Filsafat Pancasila

Pancasila merupakan falsafah negara Indonesia yang merupakan jiwa bangsa, kepribadian bangsa, sarana dan tujuan hidup bangsa, pandangan hidup bangsa, dan sumber dari segala sumber hukum negara Indonesia, serta sebagai perjanjian luhur bangsa Indonesia dalam bernegara. Sebagai sanksi untuk mengembalikan gangguan terhadap keseimbangan, keselarasan, dan keserasian dalam kehidupan masyarakat yang mengakibatkan kerusakan individual maupun masyarakat, pidana denda juga harus dikenakan dengan memperhatikan nilai- nilai Pancasila sebagai falsafah bangsa Indonesia. Pidana denda yang dilaksanakan dengan itikad atau kerelaan membayar ganti rugi kepada korban dan atau keluarganya berarti sama nilainya dengan keinginan untuk menyeimbangkan, menyelaraskan, dan menyerasikan kembali kerusakan individual akibat tindak pidana yang dilakukan oleh pelaku. Terlebih lagi, keberadaan jenis sanksi ganti rugi secara sosiologis sudah dikenal sejak beratus-ratus tahun yang lalu, bahkan sebelum hukum pidana positif berlaku di bumi Indonesia.

4) Pidana Mati Menurut Filsafat Pancasila

Setiap manusia dilengkapi dengan akal budi dan nurani yang memungkinkan manusia membedakan yang baik dari yang buruk, yang adil dari yang tidak adil, yang manusiawi dari yang tidak manusiawi, yang perlu dari yang tidak perlu, yang harus dan yang tidak harus dilakukan, yang boleh dan yang dilarang. Dengan semua itu manusia memiliki kebebasan dan kemampuan untuk menentukan sendiri pilihan tindakan yang (akan) dilakukannya serta kehidupan yang ingin dijalaninya. Oleh 
karena itu, setiap manusia bertanggung jawab untuk perbuatan yang telah atau akan dilakukannya. Adanya akal budi dan nurani itu menjadi landasan dari martabat manusia. Eksistensi manusia dikodratkan dalam kebersamaan dengan sesamanya sehingga penyelenggaraan kehidupan manusia atau proses merealisasikan diri dari setiap manusia berlangsung dalam kebersamaannya itu, yakni di masyarakat. Untuk dapat merealisasikan diri secara wajar, manusia memerlukan ketertiban dan keteraturan dalam kebersamaan itu. Oleh karena itu, manusia memiliki kodrat kebersamaan dengan sesamanya sehingga hukum harus bersifat kekeluargaan.

Hukuman mati diputuskan dan dilaksanakan oleh negara dalam kerangka tata hukum positif yang ada. Hingga kini, khususnya sejak Thomas Hobbes, banyak orang memandang atau memahami negara hanya sebagai gejala kekuasaan dan ketertiban belaka. Dalam pengertian ini, masalah hukuman mati hanyalah masalah sejauh mana negara mampu melaksanakannya dan sejauh mana efektivitas pelaksanaannya terhadap tujuan menegakkan kekuasaan dan mewujudkan ketertiban. Aspek moralitas dari hukuman mati cenderung dipandang kurang atau tidak relevan

Akan tetapi, kini semakin banyak orang yang memahami gejala negara sebagai salah satu bentuk manifestasi dari cara manusia menghadirkan diri di dunia yang terdorong oleh kodrat kebersamaannya. Karena kodratnya, manusia tidak dapat mengelakkan kebersamaannya dengan segala konsekuensinya. Untuk memungkinkan pengembangan diri secara otentik dalam kebersamaannya, dalam interaksi antarsesamanya, manusia sepanjang perjalanan sejarah telah memunculkan berbagai institusi sosial.

Demikianlah, hukum pidana dapat dipandang sebagai salah satu jawaban manusia untuk menanggulangi kecenderungan negatif yang ada dalam diri manusia dan/atau yang dapat ditimbulkan dalam proses interaksi. Kecenderungan negatif itu dapat membatalkan proses sosialisasi dan membahayakan sendi kehidupan bersama. Dengan demikian, seharusnya hukuman (sanksi pidana) mempunyai tujuan sebagai berikut:

a. Resosialisasi pelanggar hukum, yakni untuk memungkinkan pelanggar dapat berpartisipasi lagi dalam proses-proses interaksi kemasyarakatan. Dalam hal ini, hukuman ditujukan untuk mengendalikan ketaatan orang yang telah melanggar hukum sehingga dapat direintegrasikan dalam masyarakat. Tujuan ini disebut juga tujuan reformatif. 
b. Melindungi masyarakat dan para warganya. Tujuan hukuman yang dikemukakan tadi didasarkan pada asumsi bahwa hukuman juga melibatkan interaksi antara individu (warga masyarakat) dan masyarakat. Oleh karena itu, hukuman harus memperhitungkan juga hari esok pelanggar (delinquent) dan masyarakat. Dengan demikian, hukuman mati tidak konsisten dengan pengertian tujuan hukuman tadi.

Manusia selalu dihadapkan pada berbagai tantangan dan rintangan sebagai masalah hidupnya. Manusia harus, akan, dan telah berusaha untuk menjawab tantangan dan menyelesaikan masalah-masalah yang dihadapinya. Semua itu berlangsung dalam interaksi kebersamaannya. Dalam rangka memberikan jawaban terhadap tantangan-tantangan itu, manusia memunculkan berbagai institusi yang terus-menerus mengalami perkembangan dan perubahan dalam jenis, kuantitas, dan kualitasnya.

Selain itu, pengadaan dan pelaksanaan hukuman mati dapat mempunyai efek demoralisasi dalam masyarakat. Dalam kaitan ini, mungkin ada gunanya untuk mempertimbangkan Deklarasi Stockholm (Desember 1977) yang antara lain mengemukakan hal-hal berikut.

a. Hukuman mati sering digunakan sebagai alat penindasan rasial, etnis, golongan agama, anggota oposisi politik, dan golongan minoritas.

b. (Eksekusi) hukuman mati adalah suatu tindakan kekerasan dan kekerasan cenderung memancing kekerasan lagi.

c. Hukuman mati tidak terbukti memiliki daya penangkal (deteransi)

a. yang khusus.

d. Eksekusi hukuman mati bersifat irrevocable.

\section{Simpulan}

Pancasila merupakan falsafah negara Indonesia yang melandasi kehidupan bangsa Indonesia, termasuk sistem hukum pidana nasional. Sebagai bagian dari hukum material dalam hukum pidana, pembaharuan sanksi pidana di Indonesia harus memperhatikan nilai-nilai Pancasila, seperti nilai ketuhanan, nilai kemanusiaan, nilai persatuan, nilai kerakyatan, dan nilai keadilan. Penggunaan nilai-nilai Pancasila dalam pembaharuan sanksi pidana di Indonesia karena nilai-nilai tersebut sudah hidup bersama dalam masyarakat Indonesia sehingga nilai- nilai tersebut yang dapat hidup di Indonesia. Sanksi pidana yang menyimpang dari nilai-nilai Pancasila akan menyebabkan 
pertentangan atau kontroversi mengingat nilai tersebut tidak sesuai dengan nilai yang hidup di masyarakat Indonesia (sanksi tersebut dapat diterima di suatu daerah, tetapi dapat ditolak di daerah lain karena tidak sesuai dengan nilai-nilai yang hidup di masyarakat setempat).

\section{Saran}

Pidana pokok terdiri atas pidana penjara, pidana tutupan, pidana pengawasan, pidana kerja sosial, dan pidana denda. Sementara itu, pidana tambahan terdiri atas pencabutan hak tertentu, perampasan barang tertentu dan/atau tagihan, pengumuman putusan hakim, pembayaran ganti kerugian, dan pemenuhan kewajiban adat setempat atau kewajiban menurut hukum yang hidup dalam masyarakat.

\section{Daftar Pustaka:}

Badan Pembinaan Hukum Nasional, 2002, Konsep Rancangan Kitab Undang Undang Hukum Pidana (KUHP) tahun 2000, Jakarta

Arief, Barda Nawawi, 2010, Bunga Rampai Kebijakan Hukum Pidana, Perkembangan Penyusunan Konsep Baru, Jakarta, Prenadamedia , 2004, Sistem Pemidanaan dalam Ketentuan Umum Buku I RUU KUHP 2004

2005, Kebijakan Kriminalisasi Kumpul Kebo Dan Santet Dalam Konsep RUU KUHP, Seminar Nasional “ Menyongsong Berlakuknya KUHP Nasional (FH UNUD, Denpasar, 30 April 2005).

Mudzakkir, 2004, Kajian Terhadap Ketentuan Pemidanaan Dalam Draft RUU KUHP, Makalah Disampaikan pada Sosialisasi Rancangan Kitab Undang-undang Hukum Pidana yang diselenggarakan oleh Direktorat Jenderal Peraturan Perundang-undangan Departemen Kehakiman dan HAM RI, Jakarta:29 Juli 2004

Sahetapy J.E, 1982, Suatu Studi Kasus Mengenai Ancaman Pidana Mati Terhadap Pembunuhan Berencana, Jakarta, Rajawali Press.

\section{Peraturan:}

Peraturan Pemerintah Nomor 8 Tahun 1948 tentang Rumah Tutupan 